\title{
Keha tähenduse ja rolli muutumine: käsitlused eesti uue vaimsuse õpetustes ja nende järgijate seas ${ }^{1}$
}

\begin{abstract}
Marko Uibu
Teesid: Kehalisuse teema on pälvinud viimastel aastakümnetel Lääne kultuuriruumis üha rohkem tähelepanu ning ka kehasse suhtumine ja kehale omistatavad tähendused on muutunud. See tendents haakub kristliku tähendussüsteemi mõju nõrgenemise ning erinevate alternatiivmeditsiini ja uue vaimsuse käsitluste esiletõusuga. Kehalisusega seotud teemadele pööratakse uue vaimsuse õpetustes rohkelt tähelepanu: näiteks õpitakse paremini oma keha tunnetama või püütakse luua kehaga usaldusväärset partnerlus- või sõbrasuhet. Kõhutunnet või intuitsiooni käsitletakse keha sõnumina - seega antakse kehale ratsionaalselt põhjendatav viis, kuidas sõnumeid saata. Keha kuulates loodetakse tervislikumalt elada või vältida nähtamatuid ja keeruliselt tuvastatavaid riske, ent keha võib osutuda ka inimese käitumise valvuriks ja kontrollijaks, kui näiteks haigust mõtestatakse märguandena või keha sõnumina teatud käitumis- või mõtlemisviisi muutmiseks. Seeläbi kujundab uus vaimsus laiemalt ja fundamentaalsemalt inimeste elumaailmu ning avaldub muuhulgas näiteks muutunud kehatajus, mis saavutatakse kehaga suhtlemise ja keha impulsside tõlgendama õppimise abil. Vaimsete tehnikate proovimisel saadavad kehalised ja sensoorsed tundmused on ühtlasi õpetuste toimivuse kinnitajad, mis uue vaimsuse individualistlikku osalusviisi arvestades on väga oluline. Samuti võib osalejate puhul täheldada, et keha parem tunnetamine ja kehaga saadud "kontakt" on oluline argument vaimsete praktikate ja õpetustega jätkamiseks. Artikkel toetub välitöökogemusele, süvaintervjuudele ja internetipõhisele uuringule. Ehkki artiklis analüüsitavad näited pärinevad peamiselt uue vaimsuse õpetustest ning nende järgijatelt, on keha tähenduste ja rollide muutumine kahtlemata ka laiem protsess ning vihjab muutustele kultuuris ka üldisemalt.
\end{abstract}

Märksõnad: alternatiivmeditsiin, keha, kehalisus, uus vaimsus 
Stresside keele oskus võimaldab Teil kokku saada sõbraga, keda Te siiani ei tundunud - see on Teie keha,

kes räägib stresside sõnatus keeles.

Kehaga suheldes saate keelelise süvaõppe, mis on eriliselt huvitav ja ei muutu kunagi tü̈̈tavaks.

Niimoodi õpite iseennast tundma ja maailma uues valguses

vaatama.

Muutute nägijaks.

(Luule Viilma, Ellujäämise õpetus IV)

Ehkki keha võib taandada tema materiaalsele, objektiivselt olemasolevale ning kultuurivälisele olemusele, on kultuur (ning seega ka religioon) keha tajumise ja käsitlemise viiside oluline kujundaja. Kultuuri roll keha konstrueerimisel avaldub kõige selgemalt erinevates keha tajumis- ja käsitlemisviisides kas erinevatel aegadel või ka erinevates (sub)kultuurides.

Mitmete autorite (nt Shilling 2012 [1993]; Ziguras 2004) hinnangul on kehalisuse teema hakanud viimastel aastakümnetel pälvima Lääne kultuuriruumis üha rohkem tähelepanu ning ka kehasse suhtumine ja kehale omistatavad tähendused on muutunud. Üks põhjus on näiteks sagenev indiviidikesksus, mis väljendub nii kultuuris laiemalt kui ka konkreetselt kehaga seotud praktikates nagu näiteks enda mina kui projekti arendamises (vaimne ja füüsiline harimine ja treenimine). Vastutus tervise hoidmise eest tähendab ka näiteks keha jälgimist ja enda "tervikliku minaga" kontakti leidmist. Seetõttu ei ole üllatav, et holistilist arengut põhiväärtuseks pidavas uue vaimsuse keskkonnas ${ }^{2}$ seonduvad populaarsed praktikad üht- või teistpidi kehaliste tundmustega või keha taju arendamisega. Samuti pakuvad erinevad alternatiivsed teraapiad ja raviviisid $^{3}$ keha mõtestamiseks ja kehaga suhestumiseks uusi tähendusi (vt nt Coward 1989: 194).

Kehaga seotud praktikate üks oluline eesmärk on kahtlemata tervis, mis siinpoolsele, käesolevale ja maisele elule fokusseeritud kultuuris omandab erilise tähtsuse. Nagu ka Sarah Cant ja Ursula Sharma (1999: 43) oma uuringus välja toovad:

Ajal, mil keha nähakse üha enam kui "projekti", ei ole keeruline mõista selliste teraapiate ja praktikate atraktiivsust, mis rõhutavad tervise holistlikku olemust ja loovad seose fü̈̈iliste vaevuste ning inimeste emotsionaalse ja vaimse tasandi vahel, pakkudes tõepoolest lootust, et ideaalset tervist on võimalik saavutada ja hoida. 
Käesolev artikkel keskendub keha ja kehalisuse tähendustele, küsides, milliseid rolle kehale ja keha märkidele omistatakse, kuidas vaimses keskkonnas kehataju arendatakse ja miks on keha sümboli ja agendina tänapäeval muutumas nii oluliseks. Ehkki artiklis analüüsitavad näited pärinevad peamiselt vaimsetest-alternatiivsetest õpetustest ning nende järgijatelt, on keha tähenduste ja rollide muutumine kahtlemata ka laiem protsess ning vihjab muutustele kultuuris üldisemalt.

Artikkel tugineb minu välitöökogemusele ning intervjuudele uue vaimsuse praktiseerijatega, mida olen läbi viinud regulaarselt alates 2011. aasta kevadest. Materjali seas on nii poolstruktureeritud süvaintervjuud (22 inimesega) kui ka vabas vormis vestlused, mis üles märgitud erinevatel uue vaimsuse teemalistel üritustel. Samuti kasutan mõningaid tekstinäiteid vaimsetest õpetustest ja internetiaruteludest. Keha kuulamise idee ulatusest ja erinevatest vormidest laiema pildi saamiseks korraldasin 2014. aastal internetipõhise uuringu, kus erinevatele tervisepraktikatega seotud ja peamiselt avatud küsimustega ankeedile vastas 215 inimest (uuringu täpsem kirjeldus on artikli alapeatükis, kus tutvustan küsitluse tulemusi).

\section{Kehataju - kehalisuse arendamine}

Norbert Elias (1978) iseloomustab keha kultiveerimist kui ajaloolist protsessi, mis enesekontrolli ning "metsikute" kehaliste impulsside talitsemise abil püüdleb tsiviliseerituse ideaali poole. "Loomulik keha" ja sellega seonduv on Lääne kultuuris olnud pigem tõrjutud või vähemalt mitte kuigi kõrgelt hinnatud. Viimastel aastakümnetel on aga aset leidnud pööre eemale kultiveeritud keha ideaalist, mis oli sajandeid Lääne kultuurides sotsiaalselt kõrgemate klasside privileeg ja marker. Kontrolli keha üle on hakatud nägema pigem kultuurilise piiranguna ning levib romantiseeritud arusaam tervest ja terviklikust "loomulikust kehast". (Ziguras 2004: 67)

Kehale omistatavate tähenduste ja rolli muutumine näitab ka religiooni (siinkohal eelkõige kristluse ja veelgi ilmsemalt just luterluse) kui domineeriva tähendussüsteemi taandumist (vt Giordan 2009). Kui kristluses on keha ja lihalikkus takistuseks, mis tuleb pühalikkuseni jõudmiseks ületada, siis tänapäevased (uus)vaimsed lähenemised näevad keha "vahendina transtsendentse ja jumalikuga suhestumiseks - pühalikkust võib tajuda justnimelt inimese enda kehaliste kogemuste vahendusel" (Giordan 2009: 233). Loomulikult on kehalisus oluline kõikide religioonide, sealhulgas ka kristluse, puhul: religioosne kogemus kujuneb erinevates füüsilistes tegevustes nagu näiteks palvetamisel põlvitamine (McGuire 2008). Uusvaimsete praktikate puhul omandab keha 
keskse rolli nii eluliste küsimuste lahendamisel kui ka pühalikkuse ja üleloomuliku tajumisel.

Uue vaimsuse miljöös levivad väga erinevad praktikad, mis füüsilise tegevuse kaudu püüdlevad inimese üldise arengu ja avardumise poole. New age’i subkultuur aitas Läänes tutvustada mitmeid populaarseid treeninguviise nagu jooga või taijiquan. On iseloomulik, et suur osa harrastajaid peab selliseid praktikaid pigem spordiks kui vaimseks ja religioosseks eneseteostuseks - võrreldes näiteks kristliku vaimsusega on seal füüsiline osa sedavõrd oluline. Samas arendavad jooga ja muud samalaadsed praktikad kehataju ning aitavad viia vaimsete kogemusteni eriliste liigutuste, hingamise jms abil. (Karjalainen 2012)

Eestis juurdunud populaarsed praktikad ja üritused, nagu näiteks suvine tantralaager, kust 2014. aastal võttis korraldajate hinnangul osa üle 700 inimese, viitavad, et huvi just füüsiliste kogemuslike praktikate vastu on suur ${ }^{4}$. Ammu new age'i keskkonnast välja kasvanud ning jätkuvalt väga laialdaselt praktiseeritava jooga kõrval levivad Eestis vabastava hingamise, tantra, erinevad meditatsioonid või tantsuteraapiad, mille puhul inimesed soovivad ise tegutseda ja midagi erilist kogeda. Uue vaimsuse keskkonnas toimuvatele üritustele on iseloomulik, et isegi näiteks teoreetiliste ning maailma seletavate loengute lõpus võidakse teha ühiselt harjutusi, mis seotud hingamise, meditatsiooni või eriliste liigutuste ja asenditega.

Keha arendamise idee on osa laiema holistilise arengu põhimõttest. On iseloomulik, et valdkonna üldmõistena võidakse kasutada ka kombinatsiooni keha-meel-vaim (body, mind, spirit), sest usutakse, et tasakaalustatud areng peab hõlmama kõiki osiseid, sh keha. Ka Eesti uue vaimsuse miljöös pööravad mitmed autorid ja õpetajad-instruktorid erilist tähelepanu just kehalisuse teemale. Neist üks silmapaistvam on Mari Metsallik - endine Playboy kaanetüdruk, kes on nüüdseks pöördunud radikaalselt looduslähedase elu juurde, viibides suure osa aastast metsas, toitudes valgusest ja õhust. 2014. aastal andis Metsallik välja raamatu Metshaldja päevik, samuti peab ta populaarset ajaveebi, mille ühes ohtralt sotsiaalmeedias jagatud postituses kirjeldab ta kehale omistatavaid rolle ja tähendusi järgnevalt.

Mulle väga meeldivad kehaga seotud teemad, kuna minu jaoks on keha üks paljudest looduse imedest. Mulle meeldib keha vaadata, teda silitada, temaga rääkida pikalt ja põhjalikult, hellitada teda massaažiga, paitustega, kallistustega. Tihti õhtuti enne magama minekut silitan oma keha siira armastusega ning hellusega pikka aega. Tihti sirutan käed iseenda ümber ja kallistan end tugevalt. Mõnikord silitan oma juukseid, teinekord käsi või jalgu, kõhtu. Keha naudib seda väga, iga hellus tema suhtes on tema jaoks tervendav ja toitev. Keha naudib väga näiteks kreemitamist, 
sest see mõjub talle õrna silitamisena. Keha on meie jaoks kui Emake Maa, kes meid alati hoiab, kaitseb, toetab ja armastab.

Selles seisukohas esineb selgelt arusaam kehast kui väga olulisest ja intiimselt lähedasest agendist, kes vajab tähelepanu ning naudib hellitamist ja hoolt. Sellises hoolivas suhtes tähtsustatakse ka keha kuulamist, mis on üks keskne element mitmes vaimses õpetuses ning võib olla mõne inimese silmis isegi uut vaimsust defineeriv tunnus. Näiteks kirjeldas üks vaimsete praktikatega tegeleja, et tema arvates on uue vaimsuse õpetuste põhiline olemus just enda arendamises ja oma keha kuulamises.

Keha kuulamist tähtsustatakse paljudes vaimses õpetustes ja alternatiivsetes teraapiates, sealhulgas sellistes, mis seda keskseks ideeks ei pea. Näiteks demonstreeris üks pikaajaline uuring, et alternatiivmeditsiinile toetuvad homöopaadid olid oma keha suhtes tähelepanelikumad ning jälgisid pidevalt füüsilisi muutusi (Cant \& Sharma 1995). Kehaga parema kontakti saavutamist on toodud välja otsese põhjusena, miks alternatiivsete tervisepraktikate ja vaimsete õpetustega jätkatakse isegi siis, kui need meetodid konkreetset haigust ei ravinud. Just üldisem parem enesetunne ja kehataju on kaudne, kuid inimeste seisukohalt väga oluline, kasu, mida alternatiivsed meetodid pakuvad. (Baarts \& Pedersen 2009)

Ka mitmed intervjueeritud eestlastest uue vaimsuse järgijad kirjeldasid, et pöördusid õpetuse ja praktika poole küll konkreetsema eesmärgiga, kuid jäid selle või mõne muu "vaimse asjaga" pikemalt tegelema kaasnevate hüvede pärast. Näiteks 29aastane Sirle, kes leidis vaimse õpetuse elu mõtet otsides, tajub enda sõnul pärast vaimsete praktikatega tegelemist talve teistmoodi - külm ei häiri teda enam ning ta ei ole juba aastaid jäänud külmetushaigustesse. See olevat tingitud muuhulgas ka paremast kehatajust ja tugevamast kontaktist oma minaga, tema "keha-meel-vaim kui komplekt" on nüüd "paremini paigas ja toimivad".

\section{Kehalised tajud kui õpetuste toimivuse valideerijad}

Et "vaimsel turuplatsil" levivatel õpetustel puudub reeglina tugev institutsionaalne või rühma toetus, peavad vaimsusest huvitatud inimesed ideede paikapidavusele ise kinnituse leidma (vt Hervieu-Leger 2001). Ehkki mitmes aspektis sarnaneb vaimses miljöös osalemine tarbimisega, millele viitab ka mitme autori kasutatav "vaimse turuplatsi" metafoor (nt Roof 1999), on selline paralleel siiski liiga lihtsustav. Valmisolek proovida midagi uut ja alternatiivset eeldab üldiselt mingitki eelnevat usku selle tegevuse mõistlikusse. Nii nagu 
religioonis esitatavaid arusaamu peab ümbritsema teatud "tegelikkuseaura", mis näitab neid realistlike ja kehtivatena (Geertz 1993 [1966]: 2303), on ka uue vaimsuse keskkonnas usutavuse aura oluline eeltingimus erinevate tehnikateideede katsetamiseks ja edasiseks omaksvõtuks.

Uue vaimsuse õpetusega tegelema hakkamine võib olla mitmetasandiline protsess: esmalt loovad õpetusepõhised argumendid (nt väide selle traditsioonilisuse või teaduslikkuse kohta) ja/või rühma tugi (nt teiste osalejate positiivsed kogemused) praktikate või ideede poole pöördumiseks piisava usalduse. Tekkinud usutavuse foonil saavad osalejad hakata tehnikaid ise proovima ning seeläbi leidma juba isiklikule kogemusele toetuvat kinnitust nende kehtivuse kohta. Üldjuhul toovadki praktikatega tegelejad õpetuste kehtivuse toetuseks välja kogemustest ja tundmustest lähtuvaid argumente nagu "ma tundsin seda energiat enda kehas" või "ma lihtsalt tunnen end nende praktikatega tegeledes teistmoodi". Samas annavad erilised kehalised kogemused uue vaimsuse omaksvõtuks ka teatava otsetee. Nagu mitmed õpetajad-juhendajad intervjuudes välja tõid, mõjuvad füüsilised tegevused nagu näiteks vabastav hingamine tihti ka skeptikutele ning hingamisseansil millegi erilise ja "vaimse" kogemine on lahustanud ka esialgse tõrksuse ja negatiivse eelhoiaku.

Vaimsete praktikate käigus kogetud eriliste tundmuste mõju võimendab ka Eesti kontekst, kus kontroll oma psüühiliste või füüsiliste protsesside üle on kõrge ja tavaliselt inimesed ei "kaota ennast" transiseisundis ega püüa avastada erinevaid meeleseisundeid. Mary Douglasele (1970) toetudes võib näha, kuidas Lääne kultuuri ja eriti Eestit iseloomustab tugev kehaline kontroll (bodily control). Siin avaldab mõju ka kristlik kultuur ning ajaloolised ja kultuurilised arengud (nt nõukogude süsteem, mis pärssis uue vaimsuse liikumise levikut ja inimeste iseseisvaid katsetusi). Tanya Luhrmann (2011) toob välja, et just uue vaimsuse või ka karismaatiliste kristlike kirikute populaarsuse kasv on murendanud kuni 1965. aastani absoluutseks peetud arvamust, et Lääne kultuuri iseloomustab oma meelte kontrollimine ning soovimatus kogeda erilisi tundmusi, mis seonduvad meeleliste ja tajuliste dimensioonidega. Siiski püsivad Luhrmanni hinnangul muundunud teadvuseseisundite või "üleloomulike" sensoorsete kogemustega seotud tabud, mida saab laiendada ka uue vaimsuse praktikates üsna tavalistele kehalistele kogemustele nagu värinad, soojus, kehast väljumise tunne jne. Seetõttu ei leidu nende tundmuste kirjeldamiseks kultuuris sobivat sõnavara ning vaimsete praktikate pakutavad selgitused, mis sisaldavad ka laiemat ja õpetuse õigsust põhjendavat komponenti, toimivad tugevalt ideede ja praktikate kehtivuse tõestamisel ja kinnitamisel.

Selliste "eriliste" kogemuste puhul rõhutatakse sageli just nende "loomulikkust": näiteks võib praktika juhendaja esitada eriliste tundmusteni jõudmise eeldusena oskust end vabaks lasta, et saada üle intellekti kammitsevast mõ- 
just või ühiskonnas juurdunud tabudest. Seeläbi kogetud tundmus arvatakse pärinevat inimese enda kehast ning seda peetakse seetõttu lähedaseks ja loomulikuks. Sellised seisukohad on heaks näiteks keha ja kehataju kultiveeriva "tsiviliseeritusse" kõrvaleheitmise ideest (vt Ziguras 2004), et avastada loomulik, naturaalne ja "kammitsemata" keha ning seega ka iseenda sügavam ja tõelisem olemus.

Arusaamad kehast ja seda ümbritsevatest ja mõjutavatest jõududest varieeruvad kultuuriti palju ning seda on kujundanud eelkõige religioon. Erilisi (ja üleloomulikke) kehaliselt tajutavaid kogemusi võib iseloomustada kehapiiride ületamine. Mitmetes religioossetes rituaalides (näiteks seestumise käigus) kogetakse väliste jõudude kohaolekut inimese kehas. Teisalt avavad mitmed Ida traditsioonist inspireeritud õpetused arusaama füüsilisest kehast, kui kasutatakse tšakrate, eeterkeha, aura jms mõisteid. Näiteks nn peenkeha (subtle body) mudel ületab kartesiaanliku keha ja vaimu dualismi, näidates materiaalset keha kui üht paljudest energia eksisteerimise viisidest. Füüsiline keha on selle mudeli kohaselt sama palju või vähe olemas kui teadvus/vaim - kõik koosnevad ühtmoodi energiast või vibratsioonist (vt Johnston \& Barcan 2006). Eesti praktikud sellist füüsilise keha lahustumise ideed siiski universaalselt ei jaga, sest see jääb tunnetuslikult ehk liiga keeruliseks. Uue vaimsuse järgijad kasutavad küll energia mõistet, kuid see esineb pigem kui mingi universaalne jõud, mis mõjutab inimesi väljastpoolt. Sarnaselt Charles Taylori käsitlusele poorsest kehapiirist, ${ }^{5}$ kus väline võib siseneda inimese sisse (tüüpiline näide on siin vaimolendite kogemine enda kehas), esineb uue vaimsuse käsitlustes keha samuti poorsena, olles avatud energiatele-lainetele. Energia mõiste abil kirjeldatut võib seetõttu mõista kui transtsendentse tunnetamise vahevormi ühelt poolt mõjutab energia organismi, samas ei ole see siiski agendina käsitletav üleloomulik olend.

\section{Keha konstrueerimine ja temaga suhtlemine - kehalt saadavad märgid}

Keha ja vaimu erisuse kadumist ei toeta ka uue vaimsuse miljöös pigem tavapärane arusaam keha agentsusest. Mitmete uue vaimsuse arusaamade kohaselt võib keha käsitleda eraldi subjektina, kellel on justkui iseseisev teadvus ja suhtlemisvõime. Intuitsiooni või sisehäält tõlgendatakse sel juhul keha sõnumina, mis vahendab sisemist ja loomulikku teadmist (Heelas 1996: 23). Mari Metsallik kirjeldab seda oma blogipostituses (14.03.2014) nii:

Igal kehal on oma teadvus. Kes võtab omale harjumuse rääkida oma kehaga iga päev, hakkab peatselt kuulma kehalt vastuseid. Igal kehal 
on oma hä̈̈l. Keha hääl meenutab ingleid, kelle sõnumid on alati täis huumorit ja rõomu, samas andes edasi sügavat tarkust. Keha räägib meiega kui sõber sõbraga ning on täiesti selge, et armastab meid alati ja tingimusteta. Kes hakkab suhtlema oma kehaga, kuuleb tema head häält kommenteerimas teda puudutavaid tegevusi.

Keha agentsuse idee esineb paljudes õpetustes ning see ei ole midagi uut. Eestis ja teataval määral naaberriikide alternatiivset arusaama tervisest ja ka kehast on alates 1990. aastate keskpaigast kujundanud märkimisväärselt Luule Viilma - Eesti üks enimtiražeeritud taasiseseisvumisaegne autor, legendaarne ja vastuoluline arst ning vaimne õpetaja. Viilma õpetus, mis rõhutab armastamise ja andeks palumise tähtsust, näeb haiguste põhjusena stresse, mis tulenevad inimese mõtetest ja käitumisest ning mis kurnavad keha. Sarnaselt Mari Metsalliku eeltoodud tsitaadile, käsitleb ka Viilma keha kui armast sõpra või truud armastajat, kellelt pärinevad erilised märgid ja sõnumid.

Kujutage ette, et Teil on armsam, kõige kallim maailmas. Ja tema armastab Teid samuti. See kõige armsam, kõige kallim on Teie oma keha. [---] Rääkige oma kehaga! Ta on kohe valmis, sest ta armastab Teid. Keha on kõige truum armastaja. [---] Kui tunnete, kuidas kehast käivad värinad üle, puhta armastuse tunne valdab Teid ja Te tahate oma keha ümbert kinni võtta ning teda kallistada, siis on see märk, et keha mõistis. Vaid siis, kui alatiseks jääte kehaga nii suhtlema, saab haigus kaduda igaveseks. (Viilma 1. raamat)

Kehaga suhtlemise olulisust rõhutab ka Luule Viilma neljandat raamatut lõpetav pöördumine - käesoleva artikli moto tekst, mis oma lõigatud ridadega mõjub kui palve või luuletus.

Mitmed minu intervjueeritavad olid kas Viilmast või mõnest teisest õpetajast inspireeritult kehaga suhtlemist proovinud. Kõige otsesemalt nähakse keha saadetud märkidena erinevaid tundmusi (nt soojus, jahedus, värinad), aga ka head või halba enesetunnet. Üks aastaid Viilma õpetust järginud vanadaam kirjeldas oma edukat kogemust kehaga dialoogi saavutamisel:

Nagu Viilma seda õpetas, siis ma hakkasingi paluma kehalt vabandust oma vigade eest ja tänama teda, et ta on ikka vastu pidanud ja talunud mind. Niimoodi enne magamaminekut ma kõnelesin enda kehaga. Ja äkki, tunnen kõiki selliseid värinaid selgroogu mööda jooksmas... et ei tea, mis see on nü̈̈d siis küll? Siis sain aru alles, et need vabandused ja kogu see armastus, mis ma saatsin, et ta võttis selle vastu, mu keha võttis selle vastu! (73aastane naine) 
Intervjueeritava seisukohalt oli tegemist väga tugeva elamusega. Oma kehaga on ta edaspidi püüdnud alati arvestada. Arusaama, et keha nähakse kui intellekti omavat partnerit, kel on sõnumite edastamiseks oma "keel", on uue vaimsuse õpetustes ja õpetuse järgijate seas kirjeldatud ka varem (vt nt Ostenfeld-Rosenthal 2011: 158).

Kehaga usaldusliku ja arvestava suhte loomist peetakse sõnumite mõistmise aluseks. Keha arendamine, keha armastamine, silitamine (mida oli kujukalt näha Mari Metsalliku tsitaadist lk 10) ning keha säästmine erinevatest mürkidest nagu sigaretid või alkohol, on märkide mõistmise ning kehale oma sõnumite edastamise eeltingimus, mis võimaldab saavutada pea uskumatuid tulemusi. Mari Metsallik kirjeldab oma blogipostituses (14.03.2014) paastu, mille käigus ta lõpetas söömise.

3 aastat tagasi, kui alustasin järjekordset paastu, siis eelmisel õhtul enne seda lebasin voodis, silitasin oma keha ja ütlesin talle: homsest hakkame jälle paastuma. Puhastame ennast kõigest, mis meile on ebavajalik ja puhkame. Homsest palun Sinul võtta enda jaoks vajalikke toitaineid õ hust ja energiatest meie ümber, sest homsest ei võta me enam toitu füüsilisel kujul. Nii ei tundnud ma paastu ajal kordagi nälga, sest mu keha ei olnud näljas vaid toitus sellest, mis leidub õhus meie ümber.

Sellise paastu eeltingimuseks peetakse tugevat sidet oma kehaga, mis suudab "loomulikul" viisil jõuda ka tulemusteni, mida materialistlik maailmanägemus võimalikuks ei pea (nagu näiteks toitumine vaid õhust ja energiatest). Kehaga arvestamise ning kehaga usaldusliku suhte loomise idee haakub ökoloogilise vaimse arusaamaga maailmast, ehkki keha kuulamise idee on oluliselt laiem ning võib viidata ka puht-bioloogiliste märkide tähele panemisele.

\section{Uuringutulemused: keha märkide tajumine}

Lisaks vaimsete õpetuste järgijatega tehtud poolstruktureeritud intervjuudele kaardistasin keha ja kehalt saadavate märkide tähendusi 2014. aasta kvalitatiivses laia valimiga internetipõhises uuringus, ${ }^{6}$ kus 215 vastajat kirjeldasid oma suhtumisi ja kogemusi muuhulgas ka keha märkide märkamisel ja nendega arvestamisel. Vastuste põhjal võib eristada kolme põhirühma.

Esimese rühma moodustavad inimesed, kellele keha kuulamise idee on tähenduseta, sh vastajad, kelle meelest juba küsimusepüstitus keha märkidest kõlab kummaliselt. Sellesse rühma kuulujad pööravad teistest suhteliselt vähem tähelepanu pidevale tervise jälgimisele ning mõtlevad vähem tervislikele eluviisidele. 
Valdav enamus antud küsitlusele vastanuid jagas arusaama keha märkide olulisusest, ent nendele omistatavate tähenduste alusel eristub selgelt kaks rühma. Esiteks need, kellele keha märkidel on bioloogilis-füsioloogiline tähendus: füüsilist vaevust ja terviseprobleemi nähakse konkreetse patoloogia või ka ülepinge näitajana, head enesetunnet mingi tervisele kasuliku käitumise positiivse sarrustajana.

Halb enesetunne on tekkinud valest toiduvalikust, samuti kui olen töö tõttu unustanud vedelikku piisavalt tarbida. Halb enesetunne võib põhjuseks olla ligihiilivaks haiguseks. Hea enesetunne saabub siis kui tarbid piisavalt vedelikku, oled liikunud piisavalt ning sööd kerget toitu. (45aastane naine)

Keha monitoorimise idee ei ole esoteeriline või alternatiivne - seda toovad olulisena välja ka biomeditsiini spetsialistid (vt Eesmaa 2009). Eraldi rühmana on aga võimalik kirjeldada vastajaid, kelle silmis kannavad füüsilised märgid ennekõike vaimseid, sotsiaalseid ja moraalseid tähendusi. Füüsilise vaevuse põhjuseid otsitakse sel juhul valest mõtlemisest või käitumisest, samuti mingist sotsiaalsest või psühholoogilisest probleemist. Mitmel puhul tajutakse pingeid ja probleeme kultuuris levinud metafooride ja kujundite kaudu. Näiteks kirjeldab 33aastane kõrgharitud Tallinna naine, et "mure ja stress tekitavad pingeid turja peal... nagu murekoorem elaks suure raskusega seljaks, justkui sirgeks ei saa selga ega kaela". 45aastane magistrikraadiga naine kirjutas: "Tunnen, kui mind taga räägitakse... Tunne on, nagu oleks nuga seljas.”

Sellistel puhkudel on eriti selgelt nähtav, kuidas haigust tajutakse kultuuriliste sümbolite kaudu, mis omandavad sel juhul ka füüsilise dimensiooni. Näiteks üks minu intervjueeritav - 69aastane Liine, kellega käisin koos mitmel uue vaimsuse üritusel - kirjeldas oma kogemust kukekannuse ravimisel.

Käisime Kirnas, seal mõisas. Seal oli nii, et, oi, see on nii huvitav kogemus. Sa tead, mul oli kukekannus ja ma ei saanud kõndida enam. Olin kuulnud, et mine sinna Kirnasse ja läksimegi sõbrannaga [---] Istusin seal siis pinkide peal ja perenaine ütleb, et mine istu selle pingi peale. Ja lähengi istun ja mis siis hakkas... selline tunne, et seal jala sees oli selline tõrv ja noh, ja siis ma hakkasin sealt, kus see kukekannus oli, tirimamusta, vastikut, venivat, tirima... tirin-tirin, ikka ma kaua aega tirisin, pool tundi ehk tirisin ja siis äkki tuligi kõik sealt ära! Ja noh, siis ma nagu raputasin kätt ja, ja ma ei uskund oma silmi, et ta sealt ära tuleb. Ja jumal, jah, sõitsime Pärnusse ja ei olegi kukekannust, ei olegi! Jalg nii hea kerge, ei valuta ega midagi. Isiklikult mul selline kogemus. No mõjub ju! Kuidas ma saan öelda, et ei mõju! 
Haiguse kujustamine vastiku ja veniva tõrvalaadse objektina ning kehaline kogemus selle eemaldamisel on intervjueeritavale väga intensiivne. See lugu, mida Liine meeleldi räägib, on, nagu ta ka ise otsesõnu väljendab, kindel tõend mingite eriliste jõudude mõjust, sel korral näiteks siis erilisel pingil Kirna mõisas.

Nii enda kui ka teiste inimeste lugusid, mis käsitlevad tavameditsiini seisukohalt seletamatut paranemist, räägitakse meeleldi. Kinnitus õpetuste toimivuse kohta võib saabuda väga kiiresti. Luule Viilma järgi on nohu (ning seega ka nohu esimene märk ehk aevastamine) tingitud solvumisest. Kui suudad vabastada põhjuse, kaob ka haigus. Tallinnas elava 30aastase naise isiklikud kogemused kinnitavad Viilma õpetuse toimivust: "Näiteks kui jõuad enne aevastamist lasta solvumise vabaks, siis aevastust ei järgnegi. Olen saanud nohust väga ruttu lahti." Arusaama nohu põhjusest on jagatud üsna laialdaselt: 54aastane Lõuna-Eesti õpetaja kirjeldab: "Nohu tekib hetkega, kui põhjalikult vihastada. See on isiklik kogemus, nii et ei arva midagi, nii on." Siin on näha enda kogemuse tähtsust, mis annab kinnituse selgituse kehtivuse kohta.

Enda valest käitumisest või mõtlemisest põhjuste leidmine ei ole aga alati nii lihtne. Küsimusi ja arutelusid märkide äratundmise kohta leiab näiteks Luule Viilma õpetustele pühendatud veebifoorumist, mis pakub võimaluse saada oma arvamustele kinnitust ning ka jagada oma lugusid. ${ }^{7}$ Kasutaja Berry kirjutab näiteks foorumis nii:

Mul on üks valusa kurgu lugu... Olin kuu aega olnud valutava kurguga ja nii meeletult valutava, et neelata oli piin. Ma ei olnud kunagi midagi sellist kogenud - kuu aega! Tegin seda teed ja toda teed, võtsin taimetinktuuri jms... ei midagi. Olen üldiselt hea tervisega, ning see olukord oli minu jaoks hämmastav. Vabastasin stresse ja jms, mis mõneks tunniks aitas ja siis oli kõik tagasi. Mõtlesin, et OK, vaatame, kuhu see siis mind viib... ma teadsin, et tegemist on suhtlemisprobleemidega, aga ma ei suutnud näha, mis siis täpselt. [---] Tuli elimineerida see teadaanne, et minust oli saanud moslem, et ma saaksin jälle iseendaks. Kõik see protsess mu peas kestis umbes 3 minutit, ning järgmisel hetkel oli mu kurguvalu läinud! Järgmise neelamisega! Ma olin nii meeldivalt üllatunud, et kuidas see nii kiiresti juhtuda sai, aga juhtus! Tundub, et see on väga selge probleem, aga kui ma tema sees olin kaelapidi ei olnud midagi nii selge, kurk pidi minuga kuu aega rääkima, enne kui mõikama hakkas.

Berry tuvastab kurguvalu põhjusena seni isegi teadvustamata probleemi religioossusega: olles ise religiooni suhtes eestlaslikult ükskõikne, oli ta moslemist abikaasa kõrval islamiusulises riigis elades võtnud tahtmatult üle moslemi kombed. Berry hinnangul pidi tema keha (antud juhul just kurk) talle probleemist 
valude keeles pikalt rääkima - selgituse õigsust kinnitab ümberlükkamatult see, et sõnumi mõistmisel ja arvestamisel saabus paranemine väga kiiresti.

Keha märkide seostamine konkreetsete vaevustega ning nn "keha kuulamise" idee on paljudele niivõrd tavaline, et seda võidakse tajuda koguni teatava normina:

... tänasel päeval kui sul kurk valutab ja keegi küsib, et mida sa alla neelad või mis sul välja ütlemata on, see võib olla tavaline söögilauajutt. Selleks ei pea olema selgeltnägija, see on lihtsalt selline laialt levinud teave. Luule Viilma pani nagu aluse mingile väga tugevale asjale, mis on erinevaid teid ja koolkondi pidi tulnud nü̈̈d siit ja sealt jälle Eesti inimesteni. (37aastane naine)

Haiguste ja vaevuste mõistmine keha märkidena haakub Eesti üldisema uskumuste süsteemiga. End vähereligioosseks pidavad eestlased leiavad siiski, et maailmas valitseb mingi üldisem kord ja õiglus. Näiteks nõustus representatiivses uuringus üle $88 \%$ vastajatest väitega "kõik hea ja halb, mida inimene teeb, tuleb talle elu jooksul tagasi” (Jõks 2012: 294). Võib arvata, et just tervis täidab paljudel juhtudel halbade tegude eest tasuja rolli. Samuti on levinud kannatuste mõtestamine õppetunnina, mis haakub tugevalt ka uue vaimsuse ideedega. 2014. aasta representatiivses küsitluses ${ }^{8}$ nõustus $74 \%$ vastajatest väitega “Äpardused ja kannatused on õppetükid vaimse arengu teel”. Seega ei jäta ka religioosselt ükskõiksed inimesed kannatust mõtestamata ning üks võimalus on seda teha just keha märkide tähenduslikkuse kaudu. Haigussümptomite või mistahes keha märkide puhul nähakse siis keha kui loomulikku infoallikat; kehaga suhtlemine (ning usaldusliku ja kommunikatiivse suhte tekitamine) on viis, kuidas jõuda autentse infoni.

\section{Keha kui usaldusväärse ja loomuliku info allikas}

Oma kehalt pärinevate sõnumitega arvestamine võib sattuda konflikti biomeditsiiniga. 41aastane Viivi, kes paranes hiljuti uue vaimsuse keskkonnas levivate tehnikate abil raskest tervisehädast, esitas meie intervjuu käigus retoorilise küsimuse: "Kas ma peaksin kuulama oma üle töötanud ja kui nii tohib öelda, mitte ehk kõige kõrgemini motiveeritud perearsti, või siis sõnumeid, mida minu enda keha saadab?" Vastus on nii tema kui ka mitmete teiste vaimset elustiili järgivate ja kehaga suhtlevate inimeste meelest selge: kehataju on kõrvalise spetsialisti ettekirjutustest üldiselt usaldusväärsem. Sarnasele tendentsile on viidanud Katre Koppel Eesti vabastava hingamise kogukonna uurimisel, kus intuitsiooni järgimise ja keha kuulamise idee võib viia teatud meditsiinilistest 
protseduuridest keeldumiseni näiteks raseduse ajal (Koppel 2013). Otseseid konflikte arstidega püütakse siiski vältida ning tunnustatakse biomeditsiini asjatundlikkust mitmete haiguste ravimisel, mis aga õige eluviisi korral üldse ei tekigi: leitakse, et tervisliku elu ja keha kuulamisega saab haigusi edukalt vältida ning arsti vajatakse vaid erandjuhtudel.

Keha kuulamine ning loomulikuma ja puhtama elustiili järgimine on mitmete intervjueeritute sõnul vähendanud või kaotanud täielikult vajaduse arsti juurde pöörduda. Mõnel juhul oli ka aimata vastumeelsust (tava)meditsiiniliste protseduuride vastu. Üks intervjueeritu - 30aastane Sirle - kirjeldab oma otsust järgida meditsiinispetsialisti soovitusega vastuolus olevat keha sõnumit ning sisemiselt tunnetatud arusaama:

Mul oli näiteks eluaegne aneemia - seal on erinevaid tü̈̈pe, minul peaks eluaegne olema ja ma peaks nagu kogu aeg süstima ennast. Ma ei ole ennast nü̈̈d pool aastat süstinud. Mõtlesin, et vaatan, kas elan piisavalt kaua... kas see toimibki, sest põhimõtteliselt tavameditsiini kohaselt ma peaks olema surnud. Aga ei, nagu näha, elan siiski. Lihtsalt ühel hetkel ma tundsin, et ma olen terve ja ma ei pea ennast enam süstima.

Ravimi manustamise lõpetamisel saadud kogemuse tõttu on Sirle veendunud vaimsete õpetuste ja nende kultiveeritud intuitsiooni õigsuses ka laiemalt.

Jagatud praktika, kus füüsilist tundmust mõtestatakse kui kehalt lähtuvat sõnumit, annab sellele ka kindlama tõeväärtuse. Uue vaimsuse keskkonnas on levinud subjektivistlik tõepositsioon (vt Hammer 2010; Uibu 2014), kus tõde on "isiklik, eriline ja vahetul kogemusel tuginev" (Belenky jt 1997: 113). Usaldatakse kogemuste põhjal kujunenud kõhutunnet-intuitsiooni, mitte "nii-öelda autoriteete", kes näiliselt "kõike teades" tahavad lihtsalt oma ideid ja ettekirjutusi “teistele peale suruda" (McVicker Clinchy 1994: 34). Sellise tõepositsiooni aluseks olevad kõhutunne või intuitsioon on oma subjektiivsuses ja hoomamatuses aga kergesti rünnatavad. Keha kuulamise ja sõnumite äratundmise loogika ratsionaliseerib subjektiivse taju: tegemist ei ole pelgalt suvalise tundmusega, vaid kehalt kui kõige usaldusväärsemalt ja loomulikumalt infoallikalt saadud sõnumiga, millega on igati ratsionaalne arvestada.

Keha kuulamine muutub eriti oluliseks tänapäevases infost küllastunud ühiskonnas, kus inimesed kardavad erinevatest allikatest pärinevaid riske, millest suur osa on seotud tervisega. On iseloomulik, et sageli on need riskid meeleelunditega vahetult ja teadvustatult tajumatud nagu näiteks ohtlikud ained toidus või sissehingatavas õhus (Beck 2005 [1986]: 28). Toidu puhtus ja tervislikkus on samuti küsimus, millele kehalt vastuseid otsitakse. Mitmed intervjueeritud kirjeldasid erinevaid viise keha ja temalt pärinevate sõnumitega arvestamiseks toitumise puhul. Näiteks tõi 30aastane naine välja, et ta 
küsib alati poes käies oma kehalt, "mida ta vajab ja mis on talle kasulik". Ka üks teine intervjueeritav rääkis oma harjumusest poes toiduainete energiat määrata (tunnetades näiteks soojust, kui käsi aedviljale vm toiduainele asetada), et selle abil tervislik ja kehale sobiv toidukorv komplekteerida. Keha tunnetatud vajaduste põhjal langetatud toitumisalased otsused võivad olla ka väga radikaalsed nagu oli näha eelpool kirjeldatud Mari Metsalliku tahkest toidust loobumise näites.

Riskide tajumise ja usaldamatuse pinnalt võrsuvad ka mitmed vandenõuteooriad nagu näiteks arusaam nn keemiasabade (chemtrails) ohtlikkusest. Selle teooria kohaselt sisaldavad lennukite järel taevasse jäävad kondensatsioonijäljed kas kliima manipuleerimiseks või muudel põhjustel lennukitelt pritsitud kemikaale, mis aga mõjuvad halvasti inimeste tervisele, võimaldavad inimeste alateadvust kontrollida vms. ${ }^{9}$ Keemiasabade puhul võivad võimalikule ohule viidata ka kehalised märgid: näiteks hoiatab keemiasabade teemale pühendatud veebilehel üks kasutaja teisi ohtlike elementide sisalduse eest õhus, mille indikaatoriks on "imelik tunne kurgus, nagu hakkaks kohe tulema tugev nohu". Ehkki ohtlike kemikaalide sisaldus õhus on inimese seisukohalt tuvastamatu risk (Beck 2005), nähakse siiski, et teravdatud kehataju võib mõningatel juhtudel aidata ka selliste ohtude puhul.

Elukeskkonnas tajutud ohtudega püüavad tegeleda ka erinevad ühiskondlikud liikumised. Rohelise mõtteviisi juurde kuuluv puhta ja loomuliku elustiili järgimine väljendub näiteks ökokogukondade moodustamises või muul viisil loodusega kooskõlas elamise püüdes, mis on levinud ka Eestis (vt Allaste 2011). Kujutlus loodusest kui turvalisuse allikast on iseloomulik nn arenenud ja looduse üle kontrolli saavutanud ühiskondadele, kus ohtusid nähakse tulenevat pigem inimtegevusest ning loodus võrdsustatakse puhtuse ja loomulikkusega. Inimese tõelise sisemise mina täielikku ja loomulikku realiseerumist ei võimalda aga just “tehislikud ja inimeste loodud takistused” (Ziguras 2004: 69-70).

Loomulikkuse poole pürgimine ja enese tõelise mina avastamine haakub uue vaimsuse seisukohalt keskse ideega vaimsest eneseotsingust ja loomulikust arengust. Samuti esineb peaaegu kõikides alternatiivsetes tervisekäsitlustes arusaam keha kalduvusest loomuliku ja tervisliku tasakaalu poole - eeldatakse ka keha suutlikkust tervislikku ja normaalset seisu saavutada (Coward 1989: 23). Nagu ka varasemalt Eesti uuringutes välja toodud, on öko-eluviis sageli tihedalt seotud spirituaalsuse ning erinevate uusvaimsete õpetuste, praktikate, ideedega (vt Vihma 2011). Sellised mõtteviisid ja õpetused moodustavadki inimese "tegeliku”, "tõeliselt hea ja puhta" olemuse poole püüdleva mina vaimsuse ideestiku, kus kehal ja kehatajul on oluline roll. 


\section{Kokkuvõte}

Mitmed uue vaimsuse õpetused ja alternatiivmeditsiini raviviisid pööravad kehale rohkelt tähelepanu, pakkudes näiteks juhiseid, kuidas luua kehaga usaldusväärne partnerlus- või sõbrasuhe. Meditatsioonide, hingamiste ja muude füüsiliste ja vaimsete praktikate käigus saadavad kehalised ja sensoorsed tundmused on ühtlasi õpetuste toimivuse kinnitajad, mis uue vaimsuse individualistlikku osalusviisi arvestades on väga oluline. Samuti võib osalejate puhul täheldada, et keha parem tunnetamine ja kehaga saadud "kontakt" on oluline argument vaimsete praktikate ja õpetustega jätkamiseks.

Ühelt poolt pakub uue vaimsuse miljöö võimalust oma keha ja nn kõhutunnet paremini tundma õppida, teisalt avatakse laiemalt kõhutunde olemus, antakse kehale ratsionaalselt põhjendatav viis, kuidas sõnumeid saata. Keha kuulates loodetakse tervislikumalt elada või vältida nähtamatuid ja keeruliselt tuvastatavaid riske. Keha märkide jälgimine on 2014. aastal läbi viidud küsitluse tulemuste põhjal küllaltki levinud praktika, ent valdavalt arvatakse, et keha märgid (nagu haigus või peavalu) viitavad otseselt tervistkahjustavatele tegevustele nagu ületöötamine, alkoholi liigtarvitamine vms. Luule Viilma ja mitmete teiste uue vaimsuse autorite õpetustest lähtuvalt võib kehalistele tundmustele omistada ka laiemaid sotsiaalseid, psühholoogilisi ja moraalseid tähendusi, kui näiteks usutakse, et solvumine põhjustab nohu või viha ja kadedus vähki. Sellise arusaama järgimisel muutub keha justkui inimese käitumise valvuriks ja kontrollijaks, kui haigust mõtestatakse märguande või keha sõnumina teatud käitumis- või mõtlemisviisi muutmiseks. Keha märkidega arvestamise kohta osatakse tuua positiivseid näiteid: suur osa intervjueeritutest rääkis meeleldi lugusid edukatest ja mõningatel juhtudel ka väga kiiretest paranemistest, mis võisid pärineda kas iseenda või mõne tuttava kogemustest.

Uue vaimsuse keskkonnas levivaid ideid ja praktikaid ei saa otseselt käsitleda religioonina - selleks on osalus liiga episoodiline ning institutsionaalselt ebapiisavalt toetatud. Samas on uue vaimsuse pakutav rohkem kui lihtsalt elustiil või väärtused - see kujundab laiemalt ja fundamentaalsemalt inimese elumaailma ning avaldub muuhulgas näiteks muutunud kehatajus, mis saavutatakse kehaga suhtlemise ja keha impulsside tõlgendama õppimise abil. Mina-vaimsusele iseloomulik inimese "loomulikku" olemust tähtsustav mõtteviis annab tuntud maksiimile "terves kehas terve vaim" sügavama tähenduse nii tervise saavutamisel ja hoidmisel kui ka oma elumaailma kujundamisel. 


\section{Kommentaarid}

1 Uurimistööd on toetanud sihtfinantseeritav teadusteema SF180026s11 ning Euroopa Liit läbi Euroopa Regionaalarengu Fondi (Kultuuriteooria tippkeskus).

${ }^{2}$ Kõige laiemalt võibki uut vaimsust kirjeldada kui keskkonda ehk nn kultuslikku miljööd, kus levivad erinevad vaimsed-alternatiivsed ideed ja praktikad ehk "uue vaimsuse liikumised ja kultuur" (Uibu 2013: 7).

3 Vaatamata erinevatele rakendusviisidele ja fookustele on alternatiivmeditsiini ja uue vaimsuse õpetuste puhul oluliseks kokkupuutekohaks just tähelepanu keskendumine kehalisusele. Mõlemad pakuvad tavakultuuri suhtes vähem või rohkem alternatiivseid viise, kuidas keha mõtestada ning tervist selle kõige laiemas holistlikus tähenduses saavutada ja hoida.

${ }^{4}$ Ehkki paljudel juhtudel võib vaimsete seminaride-koolituste külastajaid ajendada ka nn elamusturism (põnevus selle vastu, mida tehakse tantralaagris vms) või ei tähtsusta nad praktikate vaimset poolt (siia kuulub suur osa jooga harrastajaid), on näiteks joogat nimetatud nn halliks või vahepraktikaks just seetõttu, et see võib osalejates siiski tekitada edasist huvi juba esoteerilisemate õpetuste vastu.

5 Charles Taylor (2007) kirjeldab keha piiride tajumist mõistetega "poorne" või "puhverdatud". Mitmetes šamanistlikes või vaimude kohalolu ja sekkumist tavapäraseks pidavates kultuurides on üleloomulik-jumalik tunnetatav keha sees - keha piirid on poorsed. Ehkki näiteks spiritistlikud seansid olid enne Teist maailmasõda Eestis levinud (vt Abiline 2013), on seestumispraktikad siinses kultuuris siiski ebatavalised ning keha piiride taju võib pidada puhverdatuks.

${ }^{6}$ Uuringu ankeeti levitati nii internetiportaalis delfi.ee kui ka erinevates terviseteemalistes internetifoorumites ja Facebooki gruppides. Et suur osa gruppe ja foorumeid olid kuidagi seotud alternatiivsete tervisepraktikatega, olid ka valimis selgelt üleesindatud just uuest vaimsusest ja alternatiivmeditsiinist huvitatud.

7 Ligi 4500 registreeritud kasutajaga foorum (2014. aasta septembri seisuga) ei ole isegi tervisteemaliste internetilehekülgede seas kuigi populaarne. Samas olen oma vaatluste jooksul alates 2012. aasta lõpust märganud tendentsi, et külalistele avatud foorumit loeb pidevalt arvestatav hulk registreerumata kasutajaid. Seega võib arvata, et foorumit kasutatakse kui infokanalit, sest sealsed postitused selgitavad ja laiendavad erinevate vaevuste ning märkide puhul Viilma õpetusi.

8 Lea Altnurme koostatud ning 1100 vastajaga küsitluse viis läbi uuringufirma TNS Emor 2014. aastal.

9 Vaata http://www.puhastaevas.ee/. 


\section{Allikad}

Luule Viilma Ellujäämise õpetus (http://www.luuleviilma.ee/index.php?id=7342 13. veebruar 2015).

Mari Metsallik Metshaldja päevik Facebookis (https://www.facebook.com/mari. metsallik - 13. veebruar 2015).

Luuleviilma.ee Foorum (http://foorum.luuleviilma.ee/ - 13. veebruar 2015).

Välitööde märkmed ja intervjuude transkriptsioonid.

\section{Kirjandus}

Abiline, Toomas. 2013. Uue vaimsuse eelkäijad: antroposoofia, teosoofia, vabamüürlus ja parapsühholoogia Eestis 1918-1940. Uibu, Marko (toim). Mitut usku Eesti III: Uue vaimsuse eri. Tartu: Tartu Ülikooli kirjastus, lk 37-78.

Allaste, Airi-Alina (toim) 2011. Ökokogukonnad retoorikas ja praktikas. Elustiilide uurimused. Tallinn: TLÜ kirjastus (http://www.digar.ee/arhiiv/et/raamatud/118269 13. veebruar 2015).

Baarts, Charlotte \& Kryger Pedersen, Inge 2009. Derivative Benefits: Exploring the Body through Complementary and Alternative Medicine. Sociology of Health \& Illness 31 (5), lk 719-733 (doi: 10.1111/j.1467-9566.2009.01163.x).

Beck, Ulrich 2005 [1986]. Riskiühiskond: teel uue modernsuse poole. Tartu: Tartu Ülikooli Kirjastus.

Belenky, Mary Field \& Clinchy, Blythe McVicker \& Goldberger, Nancy Rule \& Tarule, Jill Mattuck 1997. Women's Ways of Knowing: The Development of Self, Voice, and Mind (10th anniversary edn). New York: Basic Books.

Cant, Sarah \& Sharma, Ursula 1995. The reluctant profession - homoeopathy and the search for legitimacy. Work Employment and Society 9 (4), lk 743-762 (doi: 10.1177/0950017095009004007).

Cant, Sarah \& Sharma, Ursula 1999. A new medical pluralism? Alternative medicine, doctors, patients and the state. London: UCL Press.

Clinchy, Blythe McVicker 1994. On Critical Thinking and Connected Knowing. Walters, Kerry S. (toim). Re-Thinking Reason: New Perspectives in Critical Thinking. Albany, NY: State University of New York Press, lk 33-42.

Coward, Rosalind 1989. The whole truth. The myth of alternatiive health. London: Faber \& Faber.

Douglas, Mary 1970. Natural Symbols: Explorations in Cosmology. London: Barrie \& Rockliff. 
Eesmaa, Pamela 2009. Loe oma keha märke! TervisPluss september (http://tervispluss. ee/tervis-4/84D8/ - ei ole enam leitav).

Elias, Norbert 1978. The Civilizing Process: Volume One. The History of Manners. Oxford: Blackwell.

Geertz, Clifford 1993 [1966]. Religion as a cultural system. The interpretation of cultures: selected essays, Geertz, Clifford. Fontana, CA: Fontana Press, lk 87-125 (http://monoskop. org/images/5/54/Geertz_Clifford_The_Interpretation_of_Cultures_Selected_Essays.pdf_13. veebruar 2015).

Giordan, Giuseppe 2009. The Body between Religion and Spirituality. Social Compass 56 (2), lk 226-236 (doi: 10.1177/0037768609103356).

Hammer, Olav 2010. I Did It My Way? Individual Choice and Social Conformity in New Age Religion. Aupers, Stef \& Houtman Dick (toim). Religions of Modernity. Relocating the Sacred to the Self and the Digital. Leiden-Boston: Brill, lk 49-67 (doi: 10.1163/ ej.9789004184510.i-273.19).

Heelas, Paul 1996. The New Age Movement. The Celebration of the Self and the Sacralization of Modernity. Oxford: Blackwell.

Hervieu-Léger, Danièle 2001. Individualism, the Validation of Faith, and the Social Nature of Religion in Modernity. Fenn, Richard K. (toim). The Blackwell Companion to Sociology of Religion. Chichester: Blackwell Publishing, lk 161-175.

Johnston, Jay \& Barcan, Ruth 2006. Subtle Transformations: Imagining the Body in Alternative Health Practices. International Journal of Cultural Studies 9 (1), lk 25-44 (doi: 10.1177/1367877906061163).

Jõks, Eerik 2012. "Elust, usust ja usuelust 2010 tulemused" võrdlus tunnuse sugu alusel. Jõks, Eerik (toim). Astu alla rahva sekka. Artikleid ja arutlusi Eesti elanikkonna vaimulaadist. Tallinn: Eesti Kirikute Nõukogu, lk 283-317 (http://www.ekn.ee/doc/ ajakirjad/14_Elust,_usust_ja_usuelust_2010_tulemused._Vordlus_tunnuse_sugu_alusel. pdf - 13. veebruar 2015).

Karjalainen, Mira 2012. Scientific Approaches to the Body in the Spiritual-Physical Marketplace. Modern Science and the Construction of Religious Meaning. Cave, David \& Norris, Rebecca Sachs (toim). Religion and the Body. Leiden, Boston: Brill, lk 199-216.

Koppel, Katre 2013. The Body in New Age from the Perspective of the Subtle Body: The Example of the Source Breathwork Community. Journal of Ethnology and Folkloristics 7 (1), lk 49-64 (http://www.jef.ee/index.php/journal/article/view/130/pdf_96 16. veebruar 2015).

Luhrmann, Tanya Marie 2011. Hallucinations and Sensory Overrides. Annual Review of Anthropology 40, lk 71-85 (doi: 10.1146/annurev-anthro-081309-145819).

McGuire, Meredith B. 2008. Lived religion: Faith and practice in everyday life. New York: Oxford University Press.

Ostenfeld-Rosenthal, Ann 2011. Re-enchanted bodies. The significance of the spiritual dimension in Danish healing rituals. Blanes, Ruy \& Fedele, Anna (toim). Body and Soul: on Corporeality in Contemporary Religiosity. Oxford: Berghahn Books, lk 151-167. 
Roof, Wade Clark 1999. Spiritual Marketplace: Baby Boomers and the Remaking of American Religion. Princeton, NJ: Princeton University Press.

Shilling, Chris 2012 [1993]. The Body and Social Theory. (3. ja toimetatud väljaanne) London: Sage.

Ziguras, Christopher 2004. Self-Care: Embodiment, Personal Autonomy and the Shaping of Health Consciousness. London: Routledge.

Taylor, Charles 2007. A Secular Age. Cambridge, MA: Harvard University Press.

Uibu, Marko 2013. Sissejuhatus: Uue vaimsuse uurimisest ning kogumikust "Mitut usku Eesti III". Uibu, Marko (toim). Mitut usku Eesti: Uue vaimsuse eri. Tartu: Tartu Ülikooli kirjastus, lk 7-17 (http://www.tyk.ee/admin/upload/files/raamatud/1388589914. pdf - 16. veebruar 2015).

Uibu, Marko 2014. Inglid ning Inglipesa internetifoorum uue vaimsuse kandjate ja legitimeerijatena. Mäetagused 56, lk 181-204 (doi: 10.7592/MT2014.56.uibu).

Vihma, Peeter 2011. Maheporganist auramõõtmiseni. Eesti ökokogukondade tüübid. Allaste, Airi-Alina (toim). Ökokogukonnad retoorikas ja praktikas. Elustiilide uurimused. Tallinn: TLÜ kirjastus, lk 67-100.

\section{Summary}

\section{The Roles and Meanings of the Body in Estonian Spiritual Teachings}

\section{Marko Uibu}

Keywords: alternative medicine, body, embodiment, new spirituality

As an ongoing tendency in Western cultures the body has gained more importance both in mundane and transcendent issues. Contrary to the Christian (and, in Estonian context, especially Lutheran) understandings of body and flesh as obstacles, "spiritual approach makes the body itself the site of the sacred: the contemporary person relates to transcendence and the divine on the basis of the experience of his/her own body" (Giordan 2009: 233). Physical dimension is also an important element for Estonian spiritual practitioners. For instance, popular practices like yoga or taijiquan, although in Western forms taken often as mere physical training, cultivate different body perception and lead to a spiritual experience through physical means. Participation in alternative medical and spiritual practices increases people's bodily awareness, making the body more 'present'. The practices of new spirituality often emphasise the role of the body and its sensations. For example, in some teachings, the body has something that can be seen as its own 'consciousness' and/or 'language', which mediates the 'inner' and 'natural' knowledge. Practitioners try to establish a dialogue with the body, to hear its voice and interpret its signs properly. The body is seen as an 'intelligent' partner, dissolving the rigid dualism of the mind as a conscious subject and the body as a material 
object. Based on fieldwork observations, in-depth interviews and conversations as well as an Internet-based questionnaire, the article observes the different roles that the body and body-communication take in the Estonian spiritual milieu. It is visible how spiritual practices lead to different body-awarenesses and conceptualisations of the body. New spirituality offers both physical means and specific meanings for novel embodied experiences and understandings of the role of the body. 